\title{
Planning of the Clean Water Distribution System Pipeline at Griya Arwana Lestari Housing, Merauke Regency
}

\author{
Chitra Utary*, Abner Doloksaribu, Daud Andang Pasalli, Hairulla Hairulla, and Dimas D Putra \\ Department of Civil Engineering, Faculty of Engineering, Musamus University, Merauke, Indonesia
}

\begin{abstract}
Griya Arwana Lestari Housing Merauke Regency is one of the housing estates located in the area around the Merauke coast. The majority of residents of Griya Arwana Lestari housing use rainwater sources and buy water from water tanker trucks for their clean water needs. When the dry season arrives, the price of water from tanker trucks is quite expensive, making it difficult for residents of Griya Arwana Lestari housing to get clean water. So it is necessary to plan a clean water supply network system. The purpose of this study is to find out how much the discharge needs of clean water in Griya Arwana Lestari housing and find out what the diameter of the main pipe and secondary pipe are used. The method used is qualitative and quantitative based on field observations and counting the number of occupants in sustainable arowana housing then analyzing the need for clean water and then determining the diameter of the main pipe and secondary pipe. The results in this study are the required discharge in the housing is 3,973 1/s and for the main pipe diameter is 4 inches and for the secondary pipe 1 inch.
\end{abstract}

Keywords: clean water supply, network system, pipe

\section{Preliminary}

Water is one of the main needs for humans to carry out daily activities. Water is used in daily life for family needs and for the needs of public facilities. All types of water that collect above the ground surface are called surface water, including river water, reservoirs, lakes, swamps and groundwater or wells. Surface water sources come from rainwater that seeps into saturated soil that collects in a soil basin to form swamps, lakes or reservoirs [1]. Visually, the surface water looks dirty, this dirt is caused by the flow of water that carries particles of sand, mud and other objects. Usually for irrigation water needs, household needs, drinking water, industry and others [2].

Griya Arwana Lestari Housing Merauke Regency is one of the housing estates located in the area around the coast of Merauke Regency. The majority of residents of Griya Arwana Lestari housing use rainwater sources and buy water from water tanker trucks for their clean water needs. When the dry season arrives and the price of water from tanker trucks is quite expensive, it is difficult for residents of Griya Arwana Lestari housing to get clean water, especially during the dry season $[3,4]$.

\section{Methodology}

This research was conducted at the location of Griya Arwana Lestari Housing, Merauke City, Samkai Village. Geographically this housing is located at $8^{\circ} 29^{\prime} 52.33^{\prime \prime}$ north latitude and $140^{\circ} 22^{\prime} 24.24^{\prime \prime}$ east longitude

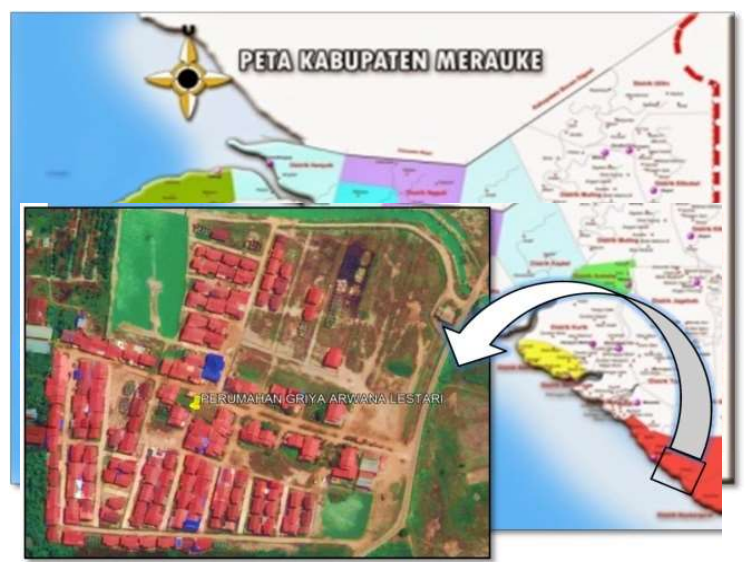

Fig. 1. Griya Arwana Lestari Housing, Merauke regency

The methods used in this research are field observation and quantitative methods. Field observations were carried out by interviewing the person in charge of housing and residents of Griya Arowana Sustainable housing. The quantitative method is to analyze the water needs of the Griya Arowana Sustainable housing and find out what the diameters of the main and secondary pipes are.

\footnotetext{
* Corresponding author : utary_ft@unmus.ac.id
} 


\section{Results and Discussion}

\subsection{Counting the number of occupants}

Based on the Law of the Republic of Indonesia No. 52 of 2009 concerning Population Development and Family Development (BPKB) [2] with the number of people per housing unit is assumed to be 5 people can be seen in the table below:

Table 1. Population calculation

\begin{tabular}{|l|l|l|l|}
\hline $\begin{array}{l}\text { House type } \\
\text { (m2) }\end{array}$ & $\begin{array}{l}\text { Number } \\
\text { of units }\end{array}$ & $\begin{array}{l}\text { Number } \\
\text { of } \\
\text { souls/unit }\end{array}$ & $\begin{array}{l}\text { Number of } \\
\text { souls }\end{array}$ \\
\hline Type 90 & 58 & 5 & 290 \\
\hline Type 70 & 53 & 5 & 265 \\
\hline Type 60 & 12 & 5 & 60 \\
\hline Type 45 & 30 & 5 & 150 \\
\hline Type 36 & 304 & 5 & 1,520 \\
\hline Shop & 8 & 7 & 56 \\
\hline \multicolumn{2}{|l|}{ Total number of souls } & 2,341 \\
\hline
\end{tabular}

\subsection{Calculating water needs}

\subsubsection{Domestic demand (Qd)}

The use of water for household needs is called domestic water needs with a public faucet connection. To calculate domestic water needs, it is necessary to have an average water requirement per person per day ( $\mathrm{L} / \mathrm{org} / \mathrm{hr}$ ) which is adjusted to the place of residence of each person because water needs will be different in each particular city category [3]. The more advanced a city is, the higher the level of human need for water[4]

Table 2. Population calculation

\begin{tabular}{|c|c|c|c|c|c|}
\hline \multirow{2}{*}{$\begin{array}{l}\text { House } \\
\text { type }\end{array}$} & \multirow{2}{*}{$\begin{array}{c}\text { Numb } \\
\text { er of } \\
\text { souls }\end{array}$} & \multirow{2}{*}{$\begin{array}{c}\text { Domes } \\
\text { tic } \\
\text { needs }\end{array}$} & \multicolumn{3}{|c|}{ Water needs } \\
\hline & & & $\mathbf{L} / \mathbf{h r}$ & $\mathrm{L} / \mathrm{sec}$ & $\mathbf{M}^{3} / \mathbf{s}$ \\
\hline $\begin{array}{l}\text { Type } \\
90\end{array}$ & 290 & 150 & 43,500 & $\begin{array}{l}0.50 \\
35 \\
\end{array}$ & $\begin{array}{l}0.0005 \\
03 \\
\end{array}$ \\
\hline $\begin{array}{l}\text { Type } \\
70\end{array}$ & 265 & 150 & 39,750 & $\begin{array}{l}0.46 \\
01 \\
\end{array}$ & $\begin{array}{l}0.0004 \\
60 \\
\end{array}$ \\
\hline $\begin{array}{l}\text { Type } \\
60\end{array}$ & 60 & 150 & 9,000 & $\begin{array}{l}0.10 \\
42 \\
\end{array}$ & $\begin{array}{l}0.0001 \\
04 \\
\end{array}$ \\
\hline $\begin{array}{l}\text { Type } \\
45\end{array}$ & 150 & 150 & 22,500 & $\begin{array}{l}0.26 \\
04 \\
\end{array}$ & $\begin{array}{l}0.0002 \\
60 \\
\end{array}$ \\
\hline $\begin{array}{l}\text { Type } \\
36 \\
\end{array}$ & 1,520 & 150 & 228.000 & $\begin{array}{l}2.63 \\
89 \\
\end{array}$ & $\begin{array}{l}0.0026 \\
39 \\
\end{array}$ \\
\hline $\begin{array}{l}\text { amou } \\
\text { nt }\end{array}$ & 2.285 & - & $\begin{array}{l}\sum_{342,750} \\
\end{array}$ & $\begin{array}{l}3,96 \\
7\end{array}$ & $\begin{array}{l}0.0039 \\
67 \\
\end{array}$ \\
\hline
\end{tabular}

\subsubsection{Non-domestic needs ( $Q n)$}

The number of people in a $60 \mathrm{~m} 2$ shophouse $=56$ people. Domestic water demand $=10 \mathrm{~L} /$ day.
Table 3. Non-domestic calculations

\begin{tabular}{|c|c|c|c|c|c|}
\hline \multirow{2}{*}{$\begin{array}{c}\text { house } \\
\text { type }\end{array}$} & \multirow{2}{*}{$\begin{array}{c}\text { numb } \\
\text { er of } \\
\text { souls }\end{array}$} & \multirow{2}{*}{$\begin{array}{c}\text { non- } \\
\text { domest } \\
\text { ic } \\
\text { needs }\end{array}$} & \multicolumn{3}{|c|}{ water needs } \\
\hline & & & L/hr & $\mathrm{L} / \mathrm{sec}$ & $\mathrm{m} 3 / \mathrm{s}$ \\
\hline 60 & 56 & 10 & 560 & $\begin{array}{c}0.0064 \\
81\end{array}$ & $\begin{array}{c}0.0000 \\
06\end{array}$ \\
\hline$\underset{n t}{\text { Amou }}$ & 56 & - & $\sum_{560}$ & $\begin{array}{c}0.0064 \\
81\end{array}$ & $\begin{array}{c}0.0000 \\
06\end{array}$ \\
\hline
\end{tabular}

\subsubsection{Average requirement ( $Q h)$}

$$
\begin{array}{ll}
\mathrm{Qdn} & =343.310 \mathrm{~L} / \mathrm{hr} \\
\mathrm{T} & =8 \text { hours } \\
\mathrm{Q}_{\mathrm{h}} & =\frac{343.310}{8} \\
\mathrm{Qh} & =42,913.75 \mathrm{~L} / \mathrm{hr}
\end{array}
$$

\subsubsection{Maximum daily requirement (Qhm)}

$\mathrm{Qhm}=1.15 \times 343.310 \mathrm{~L} / \mathrm{hr}$

$\mathrm{Qhm}=394,806.5 \mathrm{~L} / \mathrm{hr}$

\subsubsection{Needs at peak hours (Qjm)}

Qjm $=1.5 \times \frac{343.310}{24} \mathrm{~L} / \mathrm{hr}$

Qjm $=1.5 \times 14,304,583 \mathrm{~L} /$ hour

Qjm $=21,456.88 \mathrm{~L} /$ hour

\subsubsection{Maximum daily requirement (Qhm)}

$\mathrm{Q}=(342,750+560) \times 20 \%$

$\mathrm{Q}=68,662 \mathrm{~L} / \mathrm{hr}$

\subsubsection{Total water requirement (Qtot)}

$$
\begin{aligned}
& \text { Qtot }=(342,750+560+68,662) \\
& \text { Qtot }=411,972 \mathrm{~L} / \mathrm{hr} \\
& \text { Qtot }=\frac{411.972}{86400} \\
& \text { Qtot }=4.768194 \mathrm{~L} / \mathrm{sec}
\end{aligned}
$$

Qtot $=\frac{4,768194}{1000}=0,00477 \mathrm{~m}^{3} / \mathrm{det}$

\subsubsection{Calculation of discharge per housing block (Q)}

Qblock $=($ Amount Per unit $) \times($ Number of people per unit) $\times$ (need per day)

Qblock $=13$ units $\times 5$ souls $\times 150 \mathrm{~L} /$ day

Qblock $=9,750 \mathrm{~L} / \mathrm{hr}$

Qblock $=($ Amount Per unit $) \times($ Number of people per unit) $\times$ (need per day)

Qblock $=4$ units $\times 7$ people $\times 10 \mathrm{~L} /$ day

Qblock $=280 \mathrm{~L} / \mathrm{hr}$

Qblock A = 9,750 L/day + 280 L/day $=10,030 \mathrm{~L} /$ day 


\subsection{Main pipe and secondary pipe}

Calculate the diameter of the main pipe and secondary pipe. For planning the diameter of the pipe, it is by determining the speed in the pipe and getting the diameter of the pipe according to the required discharge. According to the PU candy no. 18 of 2007 the standard speed in the pipe is $(0.3-4.5 \mathrm{~m} / \mathrm{s})$ in this pipe design a speed of $0.6 \mathrm{~m} / \mathrm{s}$ is used because if the speed is too high it causes damage to the pipe and if the speed is too low there will be accumulation of sediment in the pipe[5]

\subsubsection{Main pipe diameter}

To find the diameter of the main pipe or main pipe, the following formula is used:

$$
\begin{aligned}
& \mathrm{A}=\frac{0,00477 \mathrm{~m}^{3} / \mathrm{det}}{0,6 \mathrm{~m} / \mathrm{det}} \\
& \mathrm{A}=0,0079470 \mathrm{~m}^{2} \\
& \mathrm{D}=\sqrt{\frac{0,0079470}{0,7854}} \\
& \mathrm{D}=0,1006 \mathrm{~m} \\
& \mathrm{D}=10 \mathrm{~cm} \\
& \mathrm{D}=3,96 \text { inchi } \\
& \text { Rounded up to } 4 \text { inches (4”) }
\end{aligned}
$$

\subsubsection{Second pipe diameter}

For discharge on the secondary pipe, the largest (maximum) discharge is in block 2 of the Arwana housing block, this discharge represents the dimensions of the secondary pipe.

$$
\begin{aligned}
& \mathrm{A}=\frac{0,0002951 \mathrm{~m}^{3} / \mathrm{det}}{0,6 \mathrm{~m} / \mathrm{det}} \\
& \mathrm{A}=0.0004919 \mathrm{~m}^{2} \\
& \mathrm{D}=\sqrt{\frac{\mathrm{A}}{\pi / 4}} \\
& \mathrm{D}=\sqrt{\frac{0,0004919}{0,7854}} \\
& \mathrm{D}=0,025032 \mathrm{~m} \\
& \mathrm{D}=2,5032 \mathrm{~cm} \\
& \mathrm{D}=0,99 \text { inchi }
\end{aligned}
$$

Rounded up to 1 inch (1”)

\subsection{Hydraulics Analysis}

3.4.1 Loss of high pressure on the main pipe (major losses). Loss in the pipe due to friction $\left(H_{f}\right)$.

$$
\begin{aligned}
& \mathrm{H}_{\mathrm{f}}=\frac{10,675 \cdot 15 \cdot 0,00477^{1,852}}{130^{1,852} \cdot 0,1006^{4,87}} \\
& \mathrm{H}_{\mathrm{f}}=0.0703 \mathrm{~m}
\end{aligned}
$$

3.4.2 Minor loss of pressure in main pipe (Minor Losses). Loss of pressure in pipe bends $\left(H_{b}\right)$

$\mathrm{H}_{\mathrm{b}}=0,98 \cdot \frac{0,6^{2}}{2 \cdot 9,81}$

$\mathrm{H}_{\mathrm{b}}=0.018 \mathrm{~m}$

Because the $\mathrm{Kb}$ value for 750 is not in the table, the interpolation formula is used to find the $\mathrm{Kb}$ value as follows:

$600=0.36$

$750=\mathrm{X}$ ?

$800=0.74$

$X=0,74-\left\{\frac{80-75}{80-60}\right\} \times(0,74-0,36)$

$\mathrm{X}=0,65$

So that the value of $\mathrm{Kb}$ is obtained with an angle of 750 $=0.65$

$\mathrm{H}_{\mathrm{b}}=0,65 \cdot \frac{0,6^{2}}{2 \cdot 9,81}$

$\mathrm{H}_{\mathrm{b}}=0.012 \mathrm{~m}$

The pressure loss changes the constriction in the pipe $\left(\mathrm{H}_{\mathrm{e}}\right)$.

$\mathrm{H}_{\mathrm{e}}=0,5 \cdot \frac{0,6^{2}}{2 \cdot 9,81}$

$\mathrm{H}_{\mathrm{e}}=0.009 \mathrm{~m}$

3.4.3 Loss of high pressure in the secondary pipe (major losses).Pressure loss in the pipe due to friction $\left(\mathrm{H}_{\mathrm{f}}\right)$.

$\mathrm{H}_{\mathrm{f}}=\frac{10,675 \cdot 29 \cdot 0,0000206^{1,852}}{130^{1,852} \cdot 0,0354^{4,87}}$

$\mathrm{H}_{\mathrm{f}}=0.00094 \mathrm{~m}$

Pressure loss at pipe bend $\left(\mathrm{H}_{\mathrm{b}}\right)$

$\mathrm{H}_{\mathrm{b}}=0,98 \cdot \frac{0,6^{2}}{2 \cdot 9,81}$

$\mathrm{H}_{\mathrm{b}}=0.018 \mathrm{~m}$

Because the $\mathrm{Kb}$ value for 750 is not in the table, the interpolation formula is used to find the $\mathrm{Kb}$ value as follows:

$600=0.36$

$750=\mathrm{X}$ ?

$800=0.74$

$X=0,74-\left\{\frac{80-75}{80-60}\right\} \times(0,74-0,36)$

$\mathrm{X}=0,65$

So that the value of $\mathrm{Kb}$ is obtained with an angle of 750 $=0.65$

$\mathrm{H}_{\mathrm{b}}=0,65 \cdot \frac{0,6^{2}}{2 \cdot 9,81}$

$\mathrm{Hb}=0.012 \mathrm{~m}$

The total amount of energy loss in the main and secondary pipes $\mathrm{Hf}=11.2015 \mathrm{~m} \mathrm{He}=0.1193 \mathrm{~m} \mathrm{Hb}=$ $1.3468 \mathrm{~m}$ sofor total energy loss Hplan $=\mathrm{Hf}+\mathrm{He}+\mathrm{Hb}$ $=(11.2015 \mathrm{~m})+(0.1193 \mathrm{~m})+(1.3468 \mathrm{~m})=12.67 \mathrm{~m}$.

\section{Conclusion}

The conclusion of this study regarding the planning of the clean water distribution system pipeline at the Griya Arwana Lestari Housing, Merauke Regency is the 
required discharge at the Griya Arwana Lestari housing based on the total population of L/sec or $0.004 \mathrm{~m} 3 / \mathrm{sec}$. The results of the analysis of pipe calculations obtained the diameter of the secondary pipe and the main pipe, namely the secondary pipe diameter $\mathrm{D}=0.025032 \mathrm{~m}$ or 1 inch pipe. Main pipe diameter $\mathrm{D}=0.1006 \mathrm{~m}$ or 4 -inch pipe 3,973 .

\section{References}

[1] M. Akbar, D. Lolo, and I. Djaja, "Analisis Perubahan Tata Guna Lahan Terhadap Debit Limpasan Drainase Jalan Ahmad Yani - Gang Rawa, Distrik Merauke", MJCE, vol. 1, no. 1, pp. 11-23, Oct. (2018).

[2] S. Mangihut, "Planning of the Drinking Water Distribution Piping Network System at PTPN IV Pabatu Employee Housing," Perenc. Sist. Jar. Distribution Piping. Drinking Water at Home. PTPN IV Pabatu employees, (2018).

[3] M. Akbar, C. Utary, Y. Kakerissa, and S. Asmal, "Priorities of road network development to support national food flows in Merauke District with SWOT and AHP methods," IOP Conf. Ser. Earth Environ. Sci., vol. 343, no. 1, (2019), doi: 10.1088/1755-1315/343/1/012185.

[4] M. Akbar, J. Paresa, and D. L. Pamuttu, "Analysis of the Effect of Parking on Road Bodies on Road Service Levels Analysis of the Effect of Parking on Road Bodies on Road Service Levels," IOP Conf. Ser. Mater. Sci. Eng., vol. 1125, no. 01, pp. 1-8, (2021), doi: $10.1088 / 1757-899 X / 1125 / 1 / 012014$.

[5] The law of the republic of Indonesia, "Uu no 52 of (2009)," UU No. 52 of 2009, 2009.

[6] Director General of Human Settlements, PUPR, "Guidebook for Drinking Water Development," Program, no. 20, pp. 1-47, (2007).

[7] PIS Gustave P, "Water Demand Standards and Spam Unit Components," (2010).

[8] Public Works, "Organizing the development of drinking water supply systems," (2007), [Online].Available:copyright.pu.go.id/dok/law/ permen/permen_18_2007.pdf. 